\title{
大谷石の吸水膨張特性に関する 実測評価
}

\section{MEASUREMENT EVALUATION ON CHARACTERISTICS OF EXPANSION ON WATER ABSORPTION FOR OYA STONE}

$\begin{array}{ll}\text { 鈴木裕也 }-* 1 & \text { 小西敏正 }-* 2 \\ \text { 中村成春 }-* 3 & \text { 西堀千穂 }-* 4\end{array}$

キーワード :

大谷石, 凝灰岩, 吸水膨張, 拘束变形

Keywords :

Oya stone, Tuff, Expansion on water absorption, Restraint deformation

\section{Yuya SUZUKI — $* 1 \quad$ Toshimasa KONISH $-* 2$ \\ Shigeharu NAKAMURA $-* 3 \quad$ Chiho NISHIBORI — $* 4$}

The absorption factor of an Oya stone is very high, and it sexpands greatly when it absorb water. Moreover, the compressive strength in the wet condition quite falls less than in the dry condition. Furthemore, as compared with details of the stone, the specific gravity of rough-textured Oya stone is small, and its compressive strength is also low both in the dry and wet condition. The swelling pressure is hardly produced even if the Oya stone absorbs water for a long time, and then the internal structure is vulnerable. We are going to get behind the behavior of the Oya stone in this study.

\section{1. はじめに}

大谷石は、栃木県大谷町付近に採掘場があり、古くから建築物の 内外壁用建材として幅広く使用されている。大谷石の一般的な特徴 は、次のようにまとめられる ${ }^{1)}$ 。大谷石の埋蔵分布については、10 度前後の傾斜で分布し、上々部層では巨大なみそが密集し石材とし ての価值はなく、30m 前後の上下部層では石材として優良で、 $185 \mathrm{~m}$ 前後の中部層では石材としてもっとも採掘され、100m 前後の下部 層では風化により崩れやすい石材が多い。その成因は、約 2000 万 年前の新生代第 3 紀中新世の前半に、流紋岩質火山の爆発により噴 出した火山灰や軽石を含んだ火山灰質が堆積凝固したもので、うす い緑色の凝灰岩の一種である。石基は、多量の浮石質ガラス、斜長 石、石英と少量の黒雲母角閔岩輝石で構成され、また、裮色のみそ には、含水量の多い沸石およびモンモリロナイトの粘土鉱物からな る少量の蛋白石鉄塩鉱物などの不純物を含む。さらに、石質が軟ら かいために加工が容易で、質量も軽いことが知られている。

しかしながら、その大谷石の建材としての基本的な諸特性につい ては、十分に検討されておらず、不明な点が多い。特に、水分吸収 に伴う膨張特性や、その膨張を押さえ込んだ拘束特性は、外装材や 层、擭壁など建築物の外部に使用する際に明確であるべき材料品質 と考えられるが、定量化されていない。また、屋外に露出した大谷 石は表層に剥離損傷が発生することが知られており、凍害や化学反 応などの原因が挙げられているが、拘束を受けた状態での水分吸収 に伴う膨張現象という視点での研究はほとんどなされていない。

本報告は、大谷石の吸水膨張特性を把握し、建材として使用する上で の基礎的資料を得ることを目的としている。

\section{2. 実験概要}

実験は、見掛比重試験、吸水率試験、圧縮強度試験、一面吸水膨 張試験、拘束変形試験を実施した。ここで、大谷石の岩種は、粗目、 中目、細目の 3 種に等級分けされており、それぞれに力学的性質が 異なること 2)が報告されている。そのため、本報告では粗目、中目、 細目の各 6 体、計 18 体の試験体を実験に供した。

\section{1 見掛比重試験、吸水率試験、圧縮強度試験}

本試験では、JIS A 5003 (石材) に準じて、見掛比重、吸水率、 圧縮強度を実測した。図 1 に吸水率試験の概要を示す。JIS による 圧縮強度試験では、図1により十分に吸水させた後の湿潤状態が指

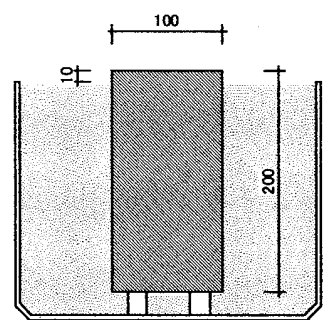

図 1. 吸水試験方法

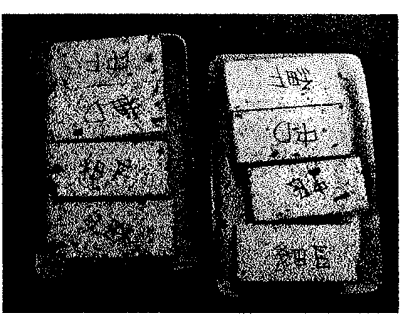

写真 1. 強度試験概要

\footnotetext{
*1 宇都宮大学大学院工学研究科 博士後期課程 $\cdot$ 工修

( ₹321-8585 栃木県宇都宮市陽東7-1-2)

*2 宇都宮大学工学部建設学科 教授・工博

*3 宇都宮大学工学部建設学科 助教授・工博

*4 宇都宮大学大学院工学研究科 博士前期課程
}

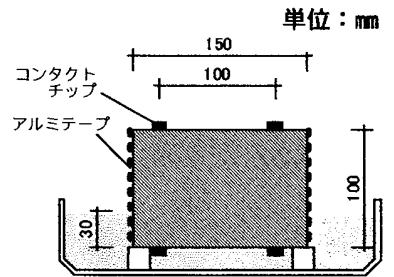

図 2. 一面吸水膨張試験方法

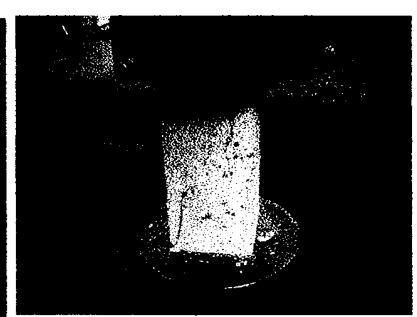

*1 Graduate Student, Graduate School of Engineering, Utsunomiya Univ., M. Eng.

2 Prof., Dept. of Architecture and Civil Engineering, Faculty of Engineering. Utsunomiya Univ., Dr. Eng.

*3 Assoc. Prof., Dept. of Architecture and Civil Engineering, Faculty of Engineering, Utsunomiya Univ., Dr. Eng.

*4 Graduate Student, Graduate School of Engineering, Utsunomiya Univ. 
定されているが、乾燥状態での性質も比較するため、 $105^{\circ} \mathrm{C} \sim 110^{\circ} \mathrm{C}$ の電気乾燥器内で恒量になるまで乾燥させた試験体と、吸水率測定 直後の湿潤状態の試験体について圧縮強度試験を行った（写真 1 ）。

\section{2 一面吸水膨張試験}

本試験では大谷石が外壁材として使用されている状況を考え、石 材の一側面のみが水分吸収面となる状態での吸水膨張状態を検討し た。試験体は、压縮強度試験と同じ石材から切り出したものを使用 し、粗目、中目、細目各 3 体、計 9 体の試験体 $100 \times 100 \times 150 \mathrm{~mm}$ を用いた。試験体は、予め $105^{\circ} \mathrm{C} \sim 110^{\circ} \mathrm{C}$ 電気乾燥器内で恒量に なるまで乾燥させた後、質量及び寸法を計測する。図 2 のように浸 水面と乾燥面の両面を測定面とし、試験体にコンタクトチップを取 り付け、コンタクトゲージによって、昰みを実測した。測定面以外 の面の水分蒸発を防ぐため、試験体の側面にはアルミテープでシー ルを施した。試験体の上部 $70 \mathrm{~mm}$ が常に水上面となるように浸水させ た状態で $20 \pm 3^{\circ} \mathrm{C} 、$ 湿度 $60 \% \mathrm{RH}$ の恒温室内に 10 日間置き、変形 状況を継続的に測定した。ここでは上面の乾燥と下面の吸水を同時 に行っているため、質量の変化は質量変化率として評価した。

\section{3 拘束変形試験}

本試験では、大谷石が外壁材や塀材として雨水がかかる部位に使 用されている状況に即し、拘束状態での吸水膨張特性を検討した。 実験に使用した試験体は、两端面を研磨して平滑にし、100×100 $\mathrm{mm}$ 断面、高さ $140 \mathrm{~mm}$ とした。大谷石岩種は細目、中目、粗目の 3 種 類とした。それぞれの岩種で無拘束の自由変形を測定するため、試 験体の側面 $100 \mathrm{~mm}$ 間でクリップゲージを取付け、伸び量を実測し、 㱏みに変換した。

拘束変形試験は、大谷石角柱体の両端部を、鉄板と鋼製ボルト 4 本からなる拘束フレームで外部拘束した状態で $20 \pm 3^{\circ} \mathrm{C}$ の恒温室内 の水中に静置し、大谷石が膨張した際に鉄板とボルトで膨張変形を 抑え、試験体に拘束応力を発生させる。銅製ボルトは発生拘束応力 に対して弾性変形すると考えられ、拘束応力作用時のボルトの歪み を測定することで、別途測定した拘束フレームのみの実測剛性を用 いて、大谷石に作用している拘束応力が間接的に定量できる。

拘束フレームの設置及び実験概要を、図 3 及び写真 2 に示す。外 部拘束用ボルトは、中央に長さ $10 \mathrm{~mm}$ の歪みゲージを貼り、それを ブチルゴムテープでシールし、防水に配虑した。拘束治具は、試験 体側面 4 面に、それぞれボルトを 1 本づつ配し、4 本のボルトで拘 束をした。歪みと温度の測定データは、データロガーを中継してパ ソコンに記録した。また、拘束フレームのみの剛性を測定するため 大谷石のない状態で拘束フレームのみの引張試験を行った。その際、 大谷石試験体断面と同面積の鋼板を拘束フレーム内側にボルトで取 付け、実際の拘束状態と同様に拘束フレームの鋼板部に面による引 張力を加えた。拘束試験体が 2 体、無拘束の自由変形試験体が 1 体 を同時に測定した。ここで、拘束を始めてからの材齢を拘束材齢と 呼ぶ。拘束試験を始めるときの試験体は、手でボルトを隙間のない よう締めた程度で拘束フレームに固定し、その状態を 0 とした。

図 4 に拘束変形試験の評価モデルの概要を示す。拘束フレーム全 体にかかる荷重 $P_{0}$ は、それぞれのボルトが負担する荷重 $P_{i}(i=1 \sim 4)$ との釣り合いから式(1)が成り立つ。

$P_{0}=P_{1}+P_{2}+P_{3}+P_{4}$

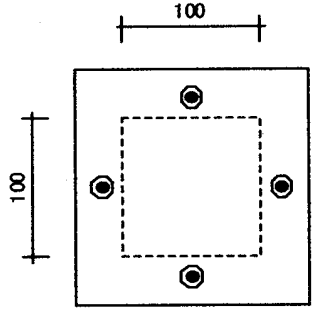

平面図

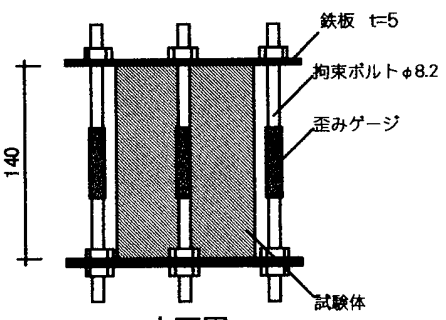

立面図

単位 : mm

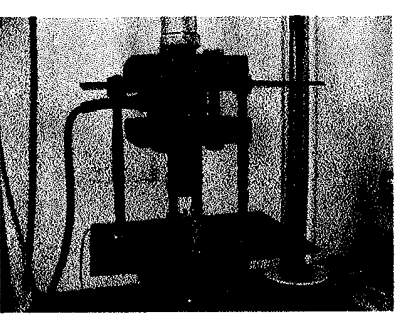

写真 2.1 拘束フレーム用性䀯定状況

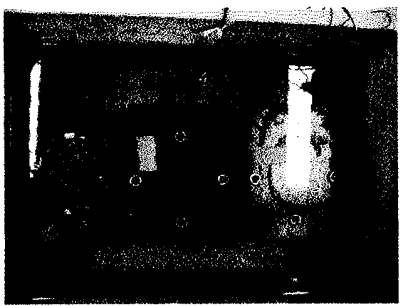

写真 2.3 試験体の吸水状況

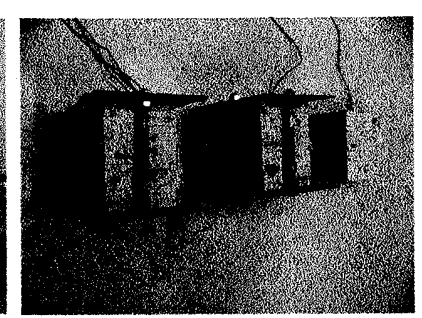

写真 2.2 拘束フレームの取付状況

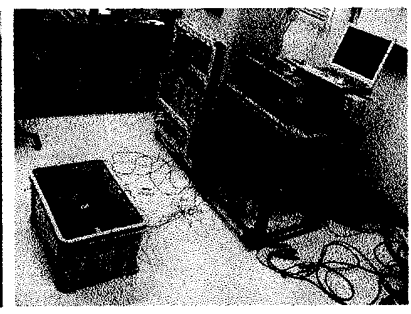

写真 2.4 拘束変形試験状況
写真 2. 拘束変形試験概要

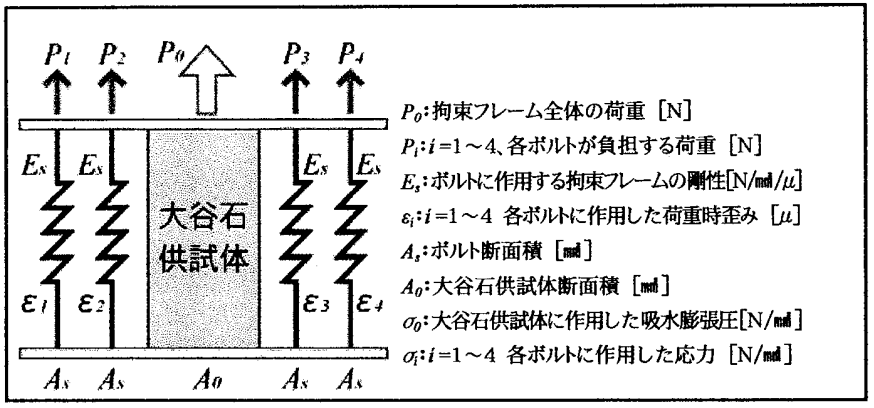

図 4. 拘束变形時の評価モデル

表 1. 見掛比重, 吸水率, 王縮強度試験結果

\begin{tabular}{|c|c|c|c|c|c|c|c|c|c|c|c|c|}
\hline \multirow{3}{*}{\multicolumn{2}{|c|}{ 試硂体 }} & \multicolumn{4}{|c|}{ 見掛比豆試硂結果 } & \multicolumn{3}{|c|}{ 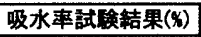 } & \multicolumn{4}{|c|}{ 压察試硂結果(N/min） } \\
\hline & & \multicolumn{2}{|c|}{ 乾嬠時 } & \multicolumn{2}{|c|}{ 湿活時"1 } & \multicolumn{2}{|c|}{ 楖定值"1 } & \multirow{2}{*}{ 䂥筮值 } & \multicolumn{2}{|c|}{ 乾嬠時 } & \multicolumn{2}{|c|}{ 湿蔨時*1 } \\
\hline & & 此重 & 平均 & 比重 & 平西 & 级水啭 & 平均 & & 強度 & 平均 & 弦度 & 平均 \\
\hline \multirow{6}{*}{ 相 } & 耝D & 1.36 & \multirow{6}{*}{1.37} & - & \multirow{6}{*}{1.71} & - & \multirow{6}{*}{24.15} & \multirow{6}{*}{24.82} & 12.83 & \multirow{6}{*}{13.79} & - & \multirow{6}{*}{5.84} \\
\hline & 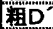 & 1.37 & & 1.71 & & 24.52 & & & - & & 5.93 & \\
\hline & 相E & 1.38 & & - & & & & & 14.62 & & & \\
\hline & 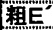 & 1.38 & & 1.70 & & 23.31 & & & $=$ & & 5.69 & \\
\hline & 租F & 1.38 & & - & & $=$ & & & 13.93 & & - & \\
\hline & 湘F" & 1.38 & & 1.71 & & 24.61 & & & - & & 5.91 & \\
\hline \multirow{6}{*}{$\begin{array}{l}\text { 中 } \\
\text { 目 }\end{array}$} & 中D & 1.41 & & - & & - & \multirow{6}{*}{23.27} & \multirow{6}{*}{24.11} & 19.00 & \multirow{6}{*}{18.29} & - & \multirow{6}{*}{6.84} \\
\hline & "中D' & 1.40 & \multirow{5}{*}{1.41} & 1.74 & \multirow{5}{*}{1.75} & 24.28 & & & $=$ & & 5.81 & \\
\hline & "中E & 1.39 & & - & & & & & 17.67 & & - & \\
\hline & 中足' & 1.42 & & 1.74 & & 22.86 & & & 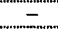 & & 7.37 & \\
\hline & QF & 1.41 & & - & & - & & & 18.19 & & $=$ & \\
\hline & 中F' & 1.43 & & 1.75 & & 22.68 & & & 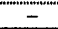 & & 7.33 & \\
\hline \multirow{2}{*}{ 口 } & 細D & 1.46 & \multirow{6}{*}{1.45} & - & \multirow{6}{*}{1.79} & & \multirow{6}{*}{24.13} & & 25.07 & \multirow{6}{*}{25.25} & $=$ & \\
\hline & 和D & 1.45 & & 1.79 & & 24.08 & & \multirow{5}{*}{23.45} & - & & 8.00 & \\
\hline \multirow{4}{*}{$\begin{array}{l}\text { 細 } \\
\text { 目 }\end{array}$} & 細E & 1.45 & & - & & - & & & 24.52 & & - & 806 \\
\hline & 細E & 1.44 & & 1.79 & & 24.62 & & & - & & 8.26 & \\
\hline & 絧F & 1.45 & & $=$ & & 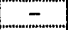 & & & 26.15 & & - & \\
\hline & 稩 $F^{\prime}$ & 1.45 & & 1.79 & & 23.67 & & & - & & 7.91 & \\
\hline
\end{tabular}

*1. JIS A 5003 に基づき計測 計算吸水率 $(\%)=\frac{\text { 表乾質量 }- \text { 絶乾質量 }}{\text { 絶乾質量 }}$ 

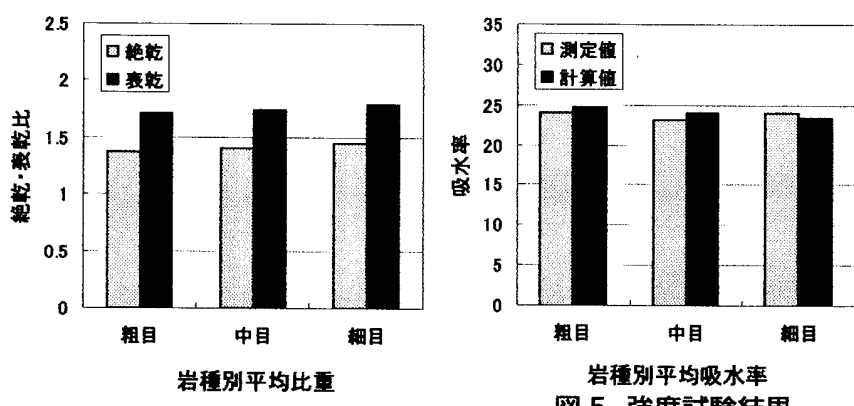

図 5. 強度試験結果

拘束フレームのみの剛性 Es は、各ボルトに生じた歪み $\varepsilon_{f}(i=1 \sim 4)$ より式(2)で評価できる。

$$
\left.\begin{array}{rl}
P_{0} & =\sigma_{1} A s+\sigma_{2} A s+\sigma_{3} A s+\sigma_{4} A s \\
& =\left(\varepsilon_{1}+\varepsilon_{2}+\varepsilon_{3}+\varepsilon_{4}\right) A s \cdot E s \\
E s & =\frac{P_{0}}{\left(\varepsilon_{1}+\varepsilon_{2}+\varepsilon_{3}+\varepsilon_{4}\right) A s}
\end{array}\right\}
$$

以上より，大谷石試験体に作用する拘束応力となる吸水膨張圧は、 式(3)で求められる。

$$
\begin{aligned}
& P_{0}=\sigma_{0} \cdot A_{0}=\left(\varepsilon_{1}+\varepsilon_{2}+\varepsilon_{3}+\varepsilon_{4}\right) A s \cdot E s \\
& \sigma_{0}=\left(\varepsilon_{1}+\varepsilon_{2}+\varepsilon_{3}+\varepsilon_{4}\right) \frac{A s \cdot E s}{A_{0}}
\end{aligned}
$$

\section{3. 実験結果及び考察}

\section{1 見掛比重試験、吸水率試験、圧縮強度試験}

表 1 及び図 5 に見挂比重試験、吸水率試験、圧縮強度試験の結果 を示す。各試験について岩種別に平均值をとり、比較を行った。

絶乾見掛比重は、粗目が平均 1.37、中目が 1.41、細目が 1.45 と なった。粗目は組織が荒く空隙が多いため、比重は最も小さい。細 目は比重が最も大きく、組織が緻密になっている。表乾比重も同じ 傾向にある。

吸水率は、粗目・中目・細目の平均で $23.9 \%$ と大きな值を示した。 見掛比重試験結果との関連を見ると、比重の小さい試験体ほど高い 吸水率を示している。これは大谷石が多孔質であり、内部に有する 空隙の影響が明確に現れているものと考えられる。得られた絶乾比

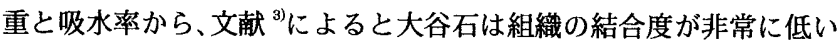
『very weak』に区分できる。

圧縮強度は、乾燥状態では粗目が $13.8 \mathrm{~N} / \mathrm{mm}$ 、中目が $18.3 \mathrm{~N} / \mathrm{mm}$ 、 細目が $25.3 \mathrm{~N} /$ m であり、目の細かさによる強度の差が顕著に現れた。 湿潤時の圧縮強度をみると、粗目が $5.8 \mathrm{~N} / \mathrm{mm}$ (乾燥時の $42 \%$ )、中目 が 6.8N/min（乾燥時の 37\%)、細目が $8.1 \mathrm{~N} / \mathrm{mm}$ （乾燥時の $32 \%$ ) と 強度が大きく低下し、岩石内部組織の結合度が低いことを補完して いる。強度の低下率は細目が最も高くなった。

\section{2 一面吸水鼔張試験}

一面吸水膨張試験の結果を図 6、図 7 に、吸水 200 時間後の平均 昰み及び質量変化率を表 2 に示す。吸水面の変形状態は、浸水直後 に大きく膨張し、その後も徐々に膨張を続けているが、粗目・中目 は 24 時間をピークに変形が止まっている。細目は微量ではあるが膨 張を続け、120 時間あたりで安定している。吸水面（下面）の最大 歪みは、粗目が $3600 \mu$ 、中目が $2450 \mu$ 、細目が $5060 \mu$ となり、 大谷石の吸水膨張変形が大きいことを表している。一方、乾燥面 (上 面）の変化は浸水後目の違いによる差異がほとんどなく、ほぼ定

\begin{tabular}{|c|c|c|c|}
\hline 岩種 & \multicolumn{2}{|c|}{ 歪み $(\mu)$} & $\begin{array}{l}\text { 質量変化率 } \\
(\%)\end{array}$ \\
\hline 粗目 & 上面 & $\begin{array}{l}2200 \\
2870\end{array}$ & 20.45 \\
\hline 中目 & 上面 & $\begin{array}{l}1900 \\
2290\end{array}$ & 18.25 \\
\hline 細目 & $\frac{\text { 上面 }}{\text { 下面 }}$ & $\frac{1830}{4520}$ & 16.41 \\
\hline
\end{tabular}
の割合で膨張を続けており、200 時間では各々の目で最終歪み値に

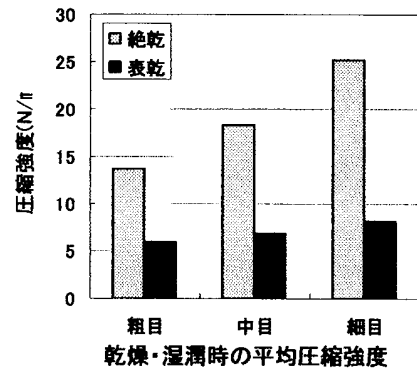

表 2. 200 時間後の一面吸水 時の平均歪み及び䨘荁変化率

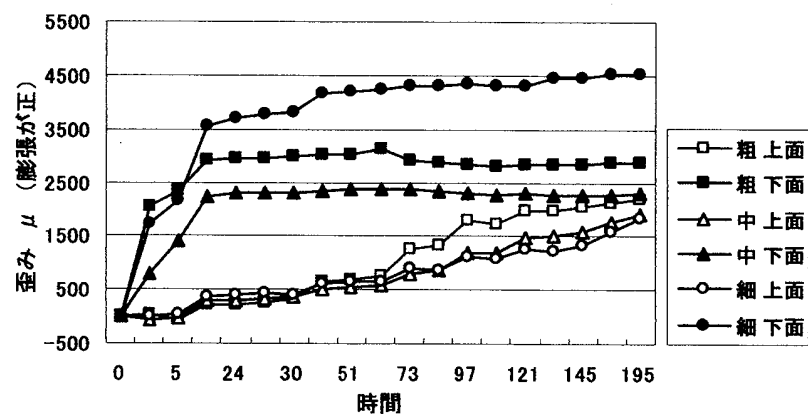

図 6. 一面吸水による歪み変化

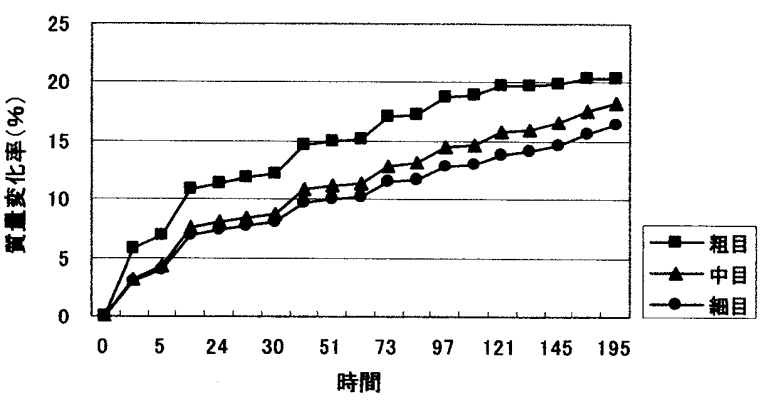

図 7. 一面吸水による質量変化

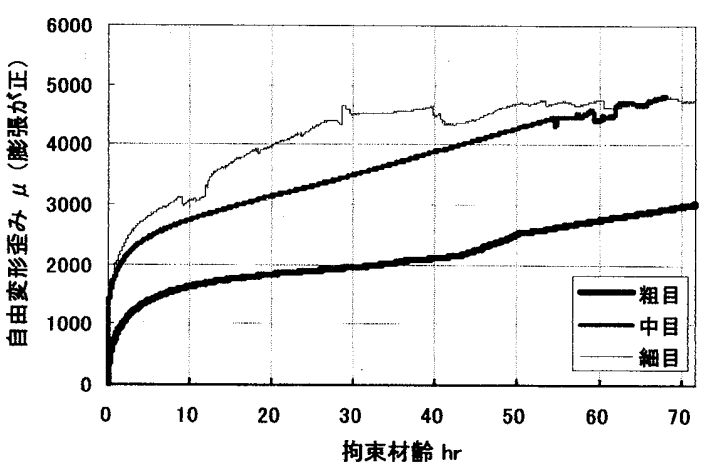

図 8. 無拘束試験体の自由変形歪み

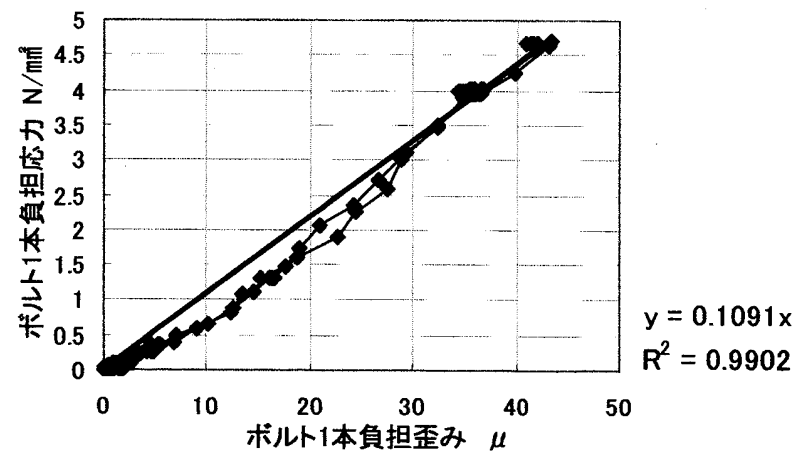

図 9. 拘束フレームの㓮性 
到達していないと思われる。吸水時の質量变化も同様な傾向が見ら れ、浸水直後に質量増加量が大きく、その後変化量が潮増しながら 質量増加が続く傾向にある。

\section{3 拘束变形試験}

図 8 に示す無拘束の自由变形歪みの経時変化は、一面吸水膨張試 験と同様, 時間が経つにつれて膨張変形が大きくなる。なお、大変 形になるにつれて、試験体側面に取り付けていたクリップゲージ用 治具の接着面がはがれてしまう状況もあり、多孔質軟質系の凝灭岩 の変形測定の困難さが現れた。

図 9 に拘束フレームの魝性の実測結果を示す。今回使用したフレ 一ムは、歪みと応力の関係を正比例とみなすことができ、その剛性 は、 $0.109((\mathrm{~N} / \mathrm{mm}) / \mu) の$ 值となった。

拘束時の外部拘束用ボルトの歪みの経時変化を用いて評価した拘 束応力となる吸収膨張圧を、図 10.1〜3に示す。

ここで、細目については、水中浸漬時の無拘束水中温度変化ボル 卜歪みを実測していたので、その水温変動歪を除去した。中目と粗 目については無拘束水中温度変化ボルト歪みを計測していなかった ため、水中温度変化にゲージの熱膨張率を掛けておおよその無拘束 時の水温変化ボルト歪みを計算し、水温による歪み補正を行ったた め、日変動の歪が少し残った結果となった。

作用応力は、どの目も非常に小さい値となり、拘束材齢 2 時間位 までに最大吸水膨張圧を示した。また、長時間の拘束につれて、吸 水膨張歪みの変化量が小さくなることで、応力緩和が生じ、吸水膨 張圧が漸減している。拘束応力の変化状況は紐目が大きく粗目が小 さい。さらに拘束直前と拘束終了直後の試験体表面に描いた方眼を 目視観察したが、明確な変化は認められなかった。

以上の結果をふまえ、吸収膨張時の拘束変形特性を考察する。吸 水時の自由変形では大きく膨張しているが、この膨張時の歪みは、 大谷石の多孔質材料的性質に鑑み、内部の結合組織がゆるみ、みか け上、スポンジのようにふくらんでいることが考えられる。大谷石 のみそ部を構成している吸水膨張歪みが大きいモンモリロナイト鉱 物自体の吸水膨張圧は、殆ど生じない結果 ${ }^{3)}$ と類似傾向にある。こ こで、粗目ではゆるみに伴う歪みの吸収が拘束当初から大きく作用 し、初期の吸水膨張圧も小さく、見かけ上、応力変化が小さくなつ たと考えられる。細目では、拘束当初に吸水膨張圧が大きく現れた が、長期間の拘束時に歪みが吸収されて、見かけ上、応力変化が大 きく見える応力緩和が生じたと推察される。別に実施した圧縮強度 試験結果でも、乾燥試験体より湿潤試験体の圧縮強度の方がかなり 低下しており、大谷石の内部構造が吸水膨張する際、結合組織がゆ るみ，スポンジの様に脆弱化していることが理解できる。

従って、吸水膨張時に拘束された大谷石の建材としての性能は、 実用範围で問題視する必要はないといえる。ただし、長期間乾湿絽 り返し作用を受けた場合などは、大谷石内部組織にダメージが蓄積 されることが考えられ、さらなる研究が必要と思われる。

\section{4. まとめ}

大谷石の吸水膨張特性を把握し、建材として使用する上での基礎 的資料を得ることを目的とした実験の結果、以下が明らかになった。 大谷石は吸水率が非常に高く、水分吸収時には大きく膨張する。 また、湿潤状態での圧縮強度は乾燥時よりも大きく低下する。さら
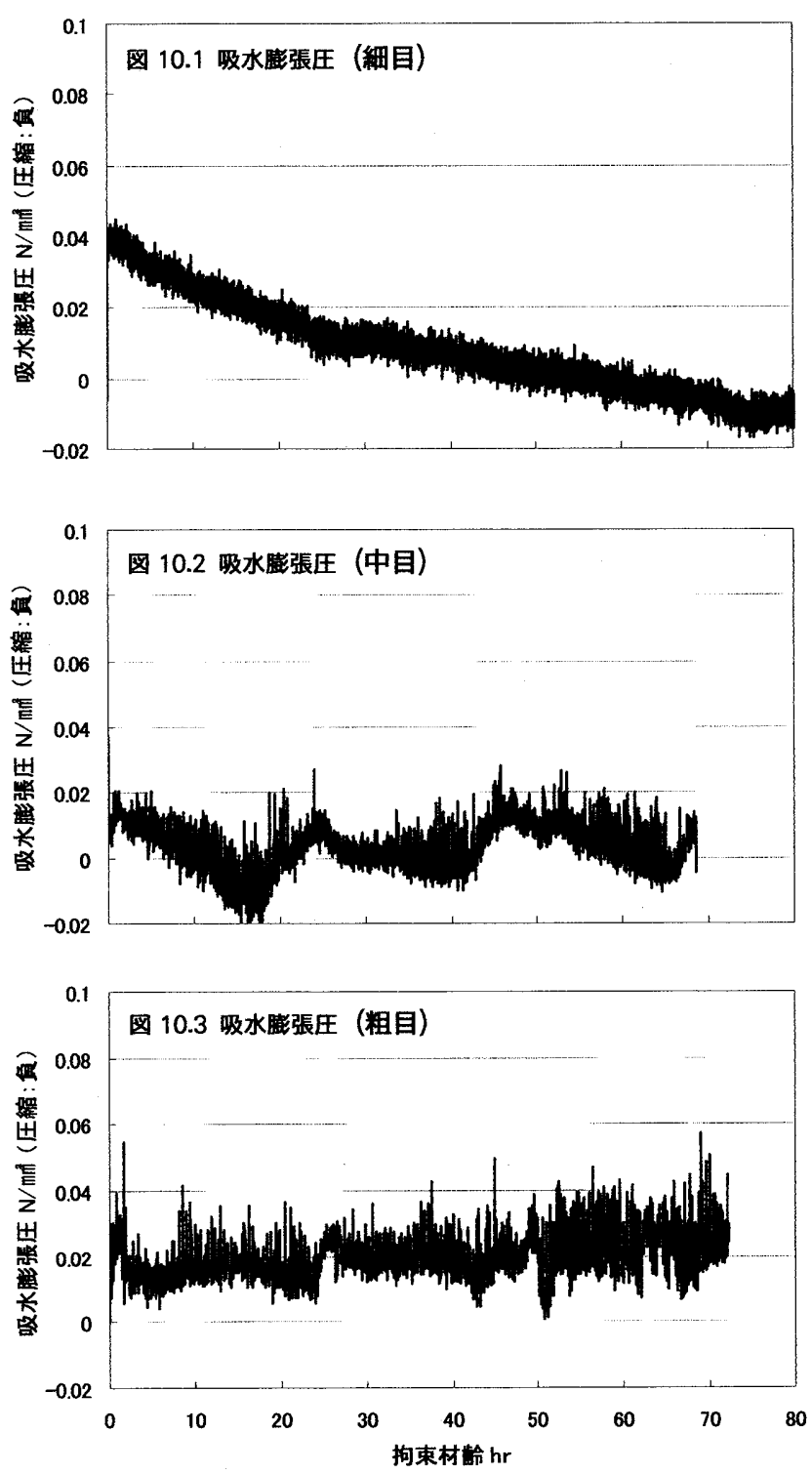

図 10. 吸水喑張圧の変化

に、粗目の大谷石は、細目と比較して比重が小さく、乾燥・吸水時 共に圧縮強度も低い。大谷石の吸水膨張時に拘束した拘束変形特性 は、水分供給が長時間にわたると、大谷石内部構造のゆるみによる 脆弱さから吸水膨張圧はほとんど生じないことがわかった。

\section{謝辞}

本研究を実施するにあたり、日本基督教団安藤記念教会に多大な ご支援を賜った。調查にご協力いただきました佐野英二牧師、間瀨 惇平氏ならびに教会関係者の方々、高橋景子氏（有限会社高橋佑知 商店）に深く感謝致します。本報のとりまとめにご協力いただきま した宇都宮大学大学院の李榮蘭氏、星里佳氏に深く感謝致します。

\section{参考文献}

1）大谷資料館ホームページ : http://www.oya909.co.jp/

2）吉岡丹, 小西敏正, 篠原道正, 田中敏夫 : 大谷石の凍害に関す る研究, 日本建築学会大会学術講演会梗概集 (北陸) 別冊材料 施工・防火・海洋, pp.97 98, 1983.9

3）地盤工学会, 岩の力学委員会 : 岩の工学的性質と設計・施工へ の応用, 地盤工学会, pp.158 161, 1974.4

[2005年 4 月20日原稿受理 2005年 7 月22日採用決定］ 